\title{
PERDAGANGAN LUAR NEGERI INDONESIA-AMERIKA SERIKAT
}

\author{
Darman \\ Management Department, School of Business Management, BINUS University \\ Jln. K. H. Syahdan No. 9, Palmerah, Jakarta Barat 11480 \\ darmantanjung@yahoo.com
}

\begin{abstract}
This study aims to identify and analyze: how international trade relations are between Indonesia and the United States, especially in the export-import of goods, particularly non-oil exports; how the value is obtained from the export-import of goods between Indonesia-United States, whether Indonesian exports to the United States greater than Indonesian import from the United States; who gets the surplus of trade between the two countries; and how big the export-import growth rate is, whether Indonesia tends to become exporter or importer. Data used in this study were a time series of the year 2008-2012. The analytical method used was the growth formula and Trade Specialization Index. Based on the trade balance, the value of Indonesian exports, both oil and non-oil, the United States has a surplus and vice versa. In other words, the United States includes a country of Indonesia's main export, in addition to Japan and China. Value of Trade Specialization Index for both oil and non-oil exports is positive above 0 to 1 , then the oil and non-oil commodities have strong competitiveness. Indonesia is likely as a means exporter of the commodity. However, based on 10 major Indonesian export commodities to the United States, as the largest foreign exchange earner for textile examples and textile products, footwear industries, electronic products, furniture, as well as horticultural commodities, is threatened lethargic, because shutdown policy decisions on the government services were feared to reduce consumption of the American people's imported products.
\end{abstract}

Keywords: international trade, Indonesia-United State of America relations, export - import of goods, surplus and deficit

\begin{abstract}
ABSTRAK
Penelitian ini bertujuan untuk mengidentifikasi dan menganalisis: hubungan perdagangan luar negeri antara Indonesia dan Amerika Serikat, khususnya ekspor-impor barang, terutama ekspor nonmigas; besar nilai yang diperoleh dari ekspor-impor barang antara Indonesia - Amerika Serikat, apakah ekspor barang Indonesia ke Amerika Serikat lebih besar daripada impor barang dari Amerika Serikat; siapa yang mendapat surplus perdagangan antara kedua negara; besar angka pertumbuhan ekspor-impor, apakah Indonesia cenderung menjadi negara eksportir atau importir. Data yang digunakan dalam penelitian ini adalah time series dari 2008-2012. Metode analisis yang digunakan adalah rumus pertumbuhan dan Indeks Spesialisasi Perdagangan (ISP). Berdasarkan Neraca Perdagangan, nilai ekspor barang Indonesia, baik migas maupun nonmigas mengalami surplus dan Amerika Serikat, dan sebaliknya. Dengan kata lain Amerika Serikat termasuk negara tujuan utama ekspor Indonesia, selain Jepang dan China. Nilai indeks spesialisasi perdagangan (ISP) baik untuk ekspor migas maupun nonmigas nilainya positif di atas 0 sampai 1, maka komoditi migas maupun nonmigas mempunyai daya saing yang kuat. Artinya Indonesia cenderung sebagai pengekspor dari komoditi tersebut. Namun berdasarkan 10 jenis komoditas ekspor utama Indonesia ke Amerika, sebagai penyumbang devisa terbesar misalnya tekstil dan produk tekstil (TPT), industri alas kaki, produk elektronik, furniture, serta komoditas holtikultura, terancam lesu, karena kebijakan keputusan shutdown terhadap pelayanan pemerintahan dikhawatirkan dapat menurunkan konsumsi produk impor rakyat Amerika.
\end{abstract}

Kata kunci: perdagangan luar negeri, hubungan Indonesia - Amerika Serikat, barang ekspor - impor, surplus dan defisit 


\section{PENDAHULUAN}

Amerika Serikat masih merupakan kekuatan utama di dunia baik dari sisi politik, militer, maupun ekonomi. Amerika Serikat merupakan negara dengan jumlah penduduk terbesar ketiga di dunia yakni sekitar 311,6 juta jiwa pada 2011 (World Bank, 2011). Pendapatan per kapita penduduknya tercatat sebesar US\$48,100 menjadikannya sebagai kekuatan ekonomi terbesar di dunia. Perekonomian Amerika Serikat sudah cukup maju baik sektor manufaktur maupun sektor jasa.

Dalam hubungan dagang, Amerika Serikat merupakan mitra dagang terbesar ketiga bagi Indonesia setelah Jepang dan China terutama pada pemerintahan Orde Baru. Neraca perdagangan menunjukkan nilai ekspor komoditas nonmigas Indonesia ke Amerika Serikat sejak Januari September 2012 tercatat sebesar US\$11,08 miliar atau sebesar 9,69\% dari keseluruhan ekspor nonmigas sebesar US\$114, 96 miliar (BPS, 2012). Ekspor nonmigas seperti karet, tekstil dan pakaian jadi, alas kaki dan mesin listrik mendominasi komoditas Indonesia yang dikirim ke Amerika Serikat. Nilai ekspor nonmigas Indonesia secara keseluruhan mengalami tren yang meningkat, kecuali tahun 2009 sebesar US\$10,850 miliar (tabel 1). Kenaikan ekspor tahun 2010 (US \$13,326 miliar), tahun 2011 (US \$15,684 miliar), dan 2012 (US \$14,5910 miliar) atau dengan tren rata-rata 7,34\% (table 1). Amerika Serikat merupakan salah satu negara tujuan impor, bersama dengan negara Asean, Jepang dan China (Kementrian Perdagangan, 2012). Nilai impor Indonesia dari Amerika Serikat pada 2012 sebesar US\$14,59 atau sebesar 6,09\% dari total impor Indonesia, lebih kecil dari nilai impor tahun 2011.

Walaupun tren semenjak 2008 menunjukkan bahwa Indonesia memiliki transaksi berjalan positif, pada 2012 terjadi defisit transaksi berjalan mencapai 3,1\% dari PDB pada awal 2012 dan 2,6\% pada kuartal ketiga 2012. Salah satu penyebab defisit transaksi berjalan sebesar US\$561,5 juta pada periode Januari- Oktober 2012 adalah impor pesawat dari Amerika Serikat (Kementrian Perdagangan, 2012). Berdasarkan data Kementrian Perindustrian RI, nilai perdagangan Indonesia-Amerika Serikat cenderung meningkat dari tahun ke tahun. Negara tujuan ekspor produk industri adalah Amerika Serikat dan Jepang. Ekspor kopi Indonesia dari tahun ke tahun sebanyak 85 persen, di antaranya diserap oleh pasar Amerika Serikat (AS) sebagai salah satu negara dengan tingkat konsumsi yang tinggi. "Ekspor kopi Indonesia sekitar 85-90 persennya diserap oleh pasar AS (Zulfikar, Direktorat Jenderal Perdagangan Luar Negeri Kementerian Perdagangan)”. Pada 2012 ekspor kopi Indonesia mencapai 320 ton atau naik 8\% dibandingkan tahun lalu. Menurut Zulfikar, potensi pasar AS merupakan salah satu yang terbesar meskipun di dunia AS bukan negara termasuk konsumen kopi terbesar. "Kalau dibandingkan dengan komposisi peminum kopi dunia, AS termasuk yang terbesar," Jumlah penduduk AS berkisar 320 juta penduduk dan jika 200 juta di antaranya adalah peminum dua gelas kopi per hari, maka jumlah konsumsi kopi di AS sangat besar.

Akibat krisis ekonomi di Amerika Serikat membawa dampak buruk untuk Indonesia. Badan Pusat Statistik (BPS) mencatat, akibat krisis ekonomi ekspor Indonesia menyusut sepanjang semester satu 2011. Kepala BPS, Rusman Heriawan menyebutkan bahwa pada Juni 2011, ekspor nonmigas Indonesia ke Amerika Serikat hanya mencapai 1,34 miliar dolar AS. Angka ini lebih kecil dibanding nilai ekspor ke Cina (US\$1,93 miliar), dan Jepang (US \$1,62 miliar). Rusman mengemukakan, sepanjang periode Januari-Juni 2011, Jepang masih merupakan negara tujuan ekspor terbesar Indonesia. Nilai ekspor Indonesia ke Jepang mencapai US\$8.970,4 juta miliar (11,35 \%). Hal ini diikuti ekspor Indonesia ke China yang mencapai US\$8.953,7 juta (11,32\%), dan Amerika Serikat dengan nilai US\$7.900,8 juta (9,99 persen).

Berdasarkan perdagangan produk ekspor Indonesia ke Amerika Serikat tahun 2008 - 2012, perlu dilakukan kajian dan analisis antara lain: (1) hubungan perdagangan luar negeri IndonesiaAmerika Serikat khususnya dalam ekspor-impor migas dan nonmigas; (2) apakah ekspor barang 
Indonesia ke Amerika lebih besar dari pada impor barang Indonesia dari Amerika Serikat dan siapa yang memperoleh surplus perdagangan di antara kedua Negara; (3) berapa besar angka pertumbuhan ekspor-impor dan surplusnya dan manfaatnya bagi Indonesia; (4) apakah Indonesia cenderung menjadi negara eksportir atau importir untuk suatu jenis produk dan bagaimana prospek perdagangan luar negeri Indonesia ke depan.

Penelitian diharapkan dapat mengetahui daya saing produk ekspor Indonesia, terutama produk unggulan seperti tekstil dan produk tekstil (TPT), industri alas kaki, produk elektronik, furnitur, serta komoditas holtikultura, dan lain-lain ke Amerika Serikat. Demikian juga penelitian bertujuan untuk mengetahui ketergantungan produk ekspor unggulan Indonesia terhadap Amerika Serikat, sebagai mitra dagang Indonesia. Selain itu, dapat diketahui spesialisasi Indonesia sebagai importir ataukah eksportir atas produk ekspor unggulan ke negara tujuan Amerika Serikat, sehingga dapat diketahui strategi maupun upaya peningkatan daya saing produk ekspor unggulan Indonesia.

\section{Tinjauan Pustaka}

\section{Teori Perdagangan Internasional}

Teori Absolute Advantage (keunggulan mutlak) dipelopori Adam Smith. Adam Smith (Appleyard, Field \& Cobb, 2006) menjelaskan bahwa perdagangan terbuka antarnegara akan membawa keuntungan bagi kedua negara. Hal tersebut terjadi jika salah satu negara tidak memperoleh surplus perdagangan dengan menciptakan defisit neraca perdagangan bagi mitra dagangnya. Adam Smith pada dasarnya menjelaskan masing-masing negara untuk mengonsentrasikan diri untuk memproduksi barang-barang yang mempunyai keunggulan mutlak (absolute advantage), kemudian mengekspor kelebihan barang produksinya tersebut.

David Ricardo (Krugman \& Obstfeld, 2005) mengemukakan teori keunggulan komparatif (comparative advantage), bahwa yang menentukan tingkat keuntungan dalam perdagangan internasional bukan berasal dari keuntungan mutlak melainkan dari keunggulan komparatif. Jika salah satu negara kurang efisien dibandingkan dengan negara lainnya dalam memproduksi dua barang, kedua negara tersebut masih dimungkinkan untuk melakukan perdagangan yang menguntungkan kedua belah pihak. Negara pertama harus melakukan spesialisasi dalam produksi komoditas yang absolute disadvantage lebih kecil dan mengimpor komoditas yang absolute disadvantage lebih besar.

Selain faktor-faktor tersebut, keunggulan kompetitif nasional juga masih dipengaruhi oleh faktor kebetulan (penemuan baru, melonjaknya harga, perubahan kurs dan konflik keamanan antarnegara). Ternyata negara berkembang yang menerapkan kebijakan promosi ekspor mengalami pertumbuhan ekonomi yang lebih baik seperti dibuktikan oleh negara-negara yang disebut sebagai East Asian Miracle. Menurut Mankiw (2003), trade openness memberikan kesempatan bagi semua perekonomian untuk mengkhususkan diri dalam hal yang paling dikuasainya, menjadikan warga negara di seluruh dunia lebih sejahtera. Pembatasan perdagangan merusak manfaat-manfaat yang diperoleh dari perdagangan ini, sehingga mengurangi kesejahteraan ekonomi secara keseluruhan. Meskipun sebagian alasan ini dapat dipertanggungjawabkan, kaum ekonom yakin bahwa perdagangan bebas adalah kebijakan yang biasanya lebih baik.

Selanjutnya Hechsher dan Ohlin atau teori H-O (Jukriadi, 2012) mengemukakan perbedaan opportunity cost suatu produk antara satu negara dengan negara lain dapat terjadi karena adanya perbedaan jumlah atau proporsi faktor produksi yang dimiliki (endowment factors) masing-masing negara. Perbedaan opportunity cost tersebut dapat menimbulkan terjadinya perdagangan internasional. Negara-negara yang memiliki faktor produksi relatif banyak/murah dalam memproduksinya akan 
melakukan spesialisasi produksi dan mengekspor barangnya. Sebaliknya, masing-masing negara akan mengimpor barang tertentu jika negara tersebut memiliki faktor produksi yang relatif langka/mahal dalam memproduksinya. Heckscher dan Ohlin menjelaskan suatu negara cenderung untuk mengekspor barang-barang yang menggunakan faktor produksi yang relatif melimpah secara intensif. Menurut Heckscher-Ohlin, suatu negara akan melakukan perdagangan dengan negara lain disebabkan negara tersebut memiliki keunggulan komparatif, yaitu keunggulan dalam teknologi dan keunggulan faktor produksi. Basis dari keunggulan komparatif adalah (a) faktor endowment, yaitu kepemilikan faktorfaktor produksi di dalam suatu negara dan (b) faktor intensity, yaitu teknologi yang digunakan didalam proses produksi, apakah labor intensity atau capital intensity.

\section{Penyebab Timbulnya Perdagangan Internasional}

Perdagangan internasional terjadi karena alasan sebagai berikut. Pertama adalah perbedaan hasil produksi. Tiap negara mempunyai kekayaan alam, modal, teknologi, dan kebudayaan yang berbeda. Oleh karena itu, tiap-tiap negara mempunyai hasil produksi yang berbeda-beda. Ada negara yang dapat memproduksi suatu barang atau jasa yang melimpah, sementara ada negara yang kekurangan hasil produksi barang atau jasa tersebut tetapi memiliki barang atau jasa lainnya. Sebagai contoh, Indonesia banyak menghasilkan produksi pertanian; Korea dan Jepang banyak menghasilkan barang-barang elektronik.

Kedua adalah perbedaan harga barang. Harga suatu barang di tiap negara berbeda. Perbedaan harga inilah yang mendorong adanya perdagangan internasional. Misalnya, harga komputer di Korea Selatan dan di Jepang lebih murah daripada harga di Indonesia mendorong orang Indonesia membeli komputer tersebut di Korea atau Jepang untuk dijual di Indonesia. Mereka melakukan perdagangan karena memperoleh keuntungan sebagai akibat dari adanya perbedaan harga jual dan harga beli.

Ketiga adalah adanya keinginan untuk meningkatkan produktivitas. Tiap-tiap negara mempunyai kebutuhan barang yang beraneka ragam. Namun secara ekonomi tiap negara lebih baik memproduksi beberapa macam barang saja kemudian melakukan perdagangan internasional. Dengan spesialisasi ini produktivitas tiap negara menjadi lebih tinggi. Banyak faktor pendorong suatu negara melakukan perdagangan internasional, di antaranya: untuk memenuhi kebutuhan barang dan jasa dalam negeri, keinginan memperoleh keuntungan dan meningkatkan pendapatan negara, adanya perbedaan kemampuan kepuasan ilmu pengetahuan dan teknologi dalam mengolah sumber daya ekonomi, adanya kelebihan produk dalam negeri sehingga perlu pasar baru untuk menjual produk tersebut, adanya perbedaaan kekayaan sumber daya alam, iklim, tenaga kerja,budaya, dan jumlah penduduk yang menyebabkan adanya perbedaan hasil produksi dan adanya keterbatsan produksi, dan adanya kesamaan selera terhadap suatu barang.

\section{Kebijakan-kebijakan Perdagangan Internasional}

Tarif adalah sejenis pajak yang dikenakan atas barang-barang yang diimpor. Tarif spesifik (Specific Tariffs) dikenakan sebagai beban tetap atas unit barang yang diimpor, misalnya \$6 untuk setiap barel minyak. Tarifold Valorem (od Valorem Tariffs) adalah pajak yang dikenakan berdasarkan persentase tertentu dari nilai barang-barang yang diimpor, misalnya tarif 25 persen atas mobil yang diimpor. Dalam kedua kasus dampak tarif akan meningkatkan biaya pengiriman barang ke suatu negara.

Subsidi ekspor adalah pembayaran sejumlah tertentu kepada perusahaan atau perseorangan yang menjual barang ke luar negeri, seperti tarif, subsidi ekspor dapat berbentuk spesifik (nilai tertentu per unit barang) atau Od Valorem (persentase dari nilai yang diekspor). Jika pemerintah memberikan subsidi ekspor, pengirim akan mengekspor, pengirim akan mengekspor barang sampai batas selisih 
harga domestik dan harga luar negeri sama dengan nilai subsidi. Dampak dari subsidi ekspor adalah meningkatkan harga di negara pengekspor, sedangkan di negara pengimpor harganya turun.

Pembatasan impor (Import Quota) merupakan pembatasan langsung atas jumlah barang yang boleh diimpor. Pembatasan ini biasanya diberlakukan dengan memberikan lisensi kepada beberapa kelompok individu atau perusahaan. Misalnya, Amerika Serikat membatasi impor keju. Hanya perusahaan-perusahaan dagang tertentu yang diizinkan mengimpor keju, masing-masing yang diberikan jatah untuk mengimpor sejumlah tertentu setiap tahun, tak boleh melebihi jumlah maksimal yang telah ditetapkan. Besarnya kuota untuk setiap perusahaan didasarkan pada jumlah keju yang diimpor tahun-tahun sebelumnya.

Bentuk lain dari pembatasan impor adalah pengekangan sukarela (Voluntary Export Restraint), yang juga dikenal dengan kesepakatan pengendalian sukarela (Voluntary Restraint Agreement $=$ ERA). VER adalah suatu pembatasan (kuota atas perdagangan yang dikenakan oleh pihak negara pengekspor dan bukan pengimpor. Contoh yang paling dikenal adalah pembatasan ekspor mobil ke Amerika Serikat yang dilaksanakan oleh Jepang sejak 1981. VER pada umumnya dilaksanakan atas permintaan negara pengimpor dan disepakati oleh negara pengekspor untuk mencegah pembatasan-pembatasan perdagangan lainnya. VER mempunyai keuntungan-keuntungan politis dan legal yang membuatnya menjadi perangkat kebijakan perdagangan yang lebih disukai dalam beberapa tahun belakangan. Namun dari sudut pandang ekonomi, pengendalian ekspor sukarela persis sama dengan kuota impor, bahwa lisensi diberikan kepada pemerintah asing dan karena itu sangat mahal bagi negara pengimpor. VER selalu lebih mahal bagi negara pengimpor dibandingan dengan tarif yang membatasi impor dengan jumlah yang sama. Bedanya yang menjadi pendapatan pemerintah dalam tarif menjadi (rent) yang diperoleh pihak asing dalam VER, sehingga VER nyatanyata mengakibatkan kerugian.

Persyaratan kandungan lokal (local content requirement) merupakan pengaturan yang mensyaratkan bahwa bagian-bagian tertentu dari unit-unit fisik, seperti kuota impor minyak AS pada 1960-an. Dalam kasus lain, persyaratan ditetapkan dalam nilai, yang mensyaratkan pangsa minimum tertentu dalam harga barang berawal dari nilai tambah domestik. Ketentuan kandungan lokal telah digunakan secara luas oleh negara berkembang yang berikhtiar mengalihkan basis manufaktur dari perakitan kepada pengolahan bahan-bahan antara (intermediate goods). Di Amerika Serikat rancangan undang-undang kandungan lokal untuk kendaraan bermotor diajukan pada 1982 namun hingga kini berlum diberlakukan.

Subsidi kredit ekspor ini semacam subsidi ekspor, hanya saja wujudnya dalam pinjaman yang disubsidi kepada pembeli. Amerika Serikat seperti juga kebanyakan negara, memiliki suatu lembaga pemerintah, ekspor-impor bank (bank ekspor-impor) yang diarahkan untuk paling tidak memberikan pinjaman-pinjaman yang disubsidi untuk membantu ekspor.

Pengendalian pemerintah (national procurement); pembelian-pembelian oleh pemerintah atau perusahaan yang diatur secara ketat dapat diarahkan pada barang-barang yang diproduksi di dalam negeri meskipun barang-barang tersebut lebih mahal daripada yang diimpor. Contoh yang klasik adalah industri telekomunikasi Eropa. Negara-negara mensyaratkan Eropa pada dasarnya bebas berdagang satu sama lain. Namun pembeli-pembeli utama dari peralatan telekonumikasi adalah perusahaan-perusahaan telepon dan di Eropa perusahaan-perusahaan ini hingga kini dimiliki pemerintah, pemasok domestik meskipun jika para pemasok tersebut mengenakan harga yang lebih tinggi dibandingkan dengan pemasok-pemasok lain. Akibatnya adalah hanya sedikit perdagangan peralatan komunikasi di Eropa.

Hambatan-hambatan birokrasi (red tape barriers); terkadang pemerintah ingin membatasi impor tanpa melakukannya secara formal. Untungnya atau sayangnya, begitu mudah untuk membelitkan standar kesehatan, keamanan, dan prosedur pabean sedemikian rupa sehingga merupakan 
perintang dalam perdagangan. Contoh klasiknya adalah Surat Keputusan Pemerintah Prancis 1982 yang mengharuskan seluruh alat perekam kaset video melalui jawatan pabean yang kecil di Poltiers yang secara efektif membatasi realisasi sampai jumlah yang relatif amat sedikit. Globalisasi ekonomi adalah kehidupan ekonomi global yang bersifat terbuka dan tidak mengenal batas-batas teritorial, atau kewilayahan antara daerah yang satu dengan daerah yang lain. Di sini dunia dianggap sebagai suatu kesatuan yang semua daerah dapat terjangkau dengan cepat dan mudah. Sisi perdagangan dan investaris menuju ke arah liberalisasi kapitalisme sehingga semua orang bebas untuk berusaha di mana saja dan kapan saja di dunia ini. Globalisasi perekonomian merupakan suatu proses kegiatan ekonomi dan perdagangan, yang negara-negara di seluruh dunia menjadi suatu kekuatan pasar yang makin terintegrasi dengan tanpa rintangan batas teritorial negara. Globalisasi perekonomian mengharuskan penghapusan seluruh batasan dan hambatan terhadap arus modal barang dan jasa.

\section{Dampak Perdagangan Internasional terhadap Perekonomian Indonesia}

Perdagangan internasional membawa pengaruh yang cukup besar dalam perekonomian Indonesia. Pengaruh tersebut ada yang bersifat positif, ada pula yang negatif. Berikut ini beberapa dampak yang ditimbulkan dari pedagangan internasional.

Dampak positif perdagangan internasional adalah berikut ini. (1) Saling membantu memenuhi kebutuhan antarnegara; terjalinnya hubungan di antara negara-negara yang melakukan perdagangan dapat memudahkan suatu Negara memenuhi barang-barang kebutuhan yang belum mampu diproduksi sendiri. Mereka dapat saling membantu mengisi kekurangan dari setiap negara, sehingga kebutuhan masyarakat terpenuhi. (2) Meningkatkan produktivitas usaha; dengan adanya perdagangan internasional, kemajuan teknologi yang digunakan dalam proses produksi akan meningkat. Meningkatnya teknologi yang lebih modern dapat meningkatkan produktivitas perusahaan dalam menghasilkan barang-barang. (3) Mengurangi pengangguran; perdagangan internasional dapat membuka kesempatan kerja baru, sehingga hal ini menjadi peluang bagi tenaga kerja baru untuk memasuki dunia kerja. Makin banyak tenaga kerja yang digunakan oleh perusahaan, maka pengangguran dapat berkurang. (4) Menambah pendapatan devisa bagi negara; dalam kegiatan perdagangan internasional, setiap negara akan memperoleh devisa. Makin banyak barang yang dijual di negara lain, perolehan devisa bagi negara akan makin banyak. (5) Mendorong kemajuan ilmu pengetahuan dan tekonologi; adanya perdagangan antarnegara memungkinkan suatu negara untuk mempelajari teknik produksi yang lebih efisien. Perdagangan luar negeri memungkinkan negara tersebut mengimpor mesin-mesin atau alat-alat modern untuk melaksanakan teknik produksi dan cara produksi yang lebih baik.

Dampak negatif perdagangan internasional adalah (1) adanya ketergantungan dengan negaranegara pengimpor; untuk memenuhi kebutuhan barang-barang yang tidak diproduksi dalam negeri, pemerintah akan mengimpor dari negara lain. Kegiatan mengimpor ini dapat mengakibatkan ketergantungan dengan negara pengimpor. (2) Masyarakat menjadi konsumtif; banyaknya barangbarang impor yang masuk ke dalam negeri menyebabkan semakin banyak barang yang ada di pasar baik dari jumlah, jenis, dan bentuknya. Akibatnya akan mendorong seseorang untuk lebih konsumtif, karena semakin banyak barang-barang pilihan yang dapat dikonsumsi. (3) Mematikan usaha-usaha kecil; perdagangan internasional dapat menimbulkan persaingan industri dengan negara-negara lain. Industri yang tidak mampu bersaing tentu akan mengalami kerugian, sehingga akan mematikan usaha produksinya. Dalam jangka panjang, hal ini dapat menyebabkan pengangguran. (4) Kualitas sumber daya yang rendah; rendahnya kualitas tenaga kerja dapat mengahambat perdagangan internasional. Jika sumber daya manusia rendah, kualitas dari hasil produksi akan rendah pula. Suatu negara yang memiliki kualitas barang rendah akan sulit bersaing dengan barang-barang yang dihasilkan oleh negara lain yang kualitasnya lebih baik. (5) Pembayaran antarnegara sulit dan risikonya besar. Pada saat melakukan kegiatan perdagangan internasional, negara pengimpor akan mengalami kesulitan dalam hal pembayaran. Jika pembayaran dilakukan secara langsung, hal tersebut akan mengalami kesulitan. Selain itu juga mempunyai risiko yang sangat besar. 


\section{METODE PENELITIAN}

Penelitian ini menggunakan pendekatan eksploratif deskriptif dengan menganalisis daya saing produk ekspor unggulan Indonesia. Untuk mengukur dan mengetahui kontribusi produk ekspor unggulan Indonesia, dapat digunakan formula sebagai berikut:

\section{Rumus Pertumbuhan}

$$
\begin{aligned}
& \quad \mathrm{P}_{\mathrm{t}}=\mathrm{P}_{0}(1+\mathrm{r})^{\mathrm{t}} \\
& \text { dengan: } \\
& \mathrm{P}_{\mathrm{t}}=\text { Perkiraan impor atau ekspor tahun ke } \mathrm{t} \\
& \mathrm{P}_{0}=\text { Perkiraan impor atau ekspor tahun dasar } \\
& \mathrm{r}=\text { Tingkat pertumbuhan } \\
& \mathrm{t}=\text { Periode tahun yang diamati }
\end{aligned}
$$

\section{Indeks Spesialisasi Perdagangan (ISP)}

Indeks Spesialisasi Perdagangan (ISP) digunakan untuk menganalisis posisi atau tahapan perkembangan suatu produk. ISP dapat menggambarkan apakah suatu jenis produk Indonesia cenderung menjadi negara eksportir atau importir. Secara matematika, ISP dapat dirumuskan sebagai berikut:

$$
\operatorname{ISP}=\frac{\left(\mathrm{X}_{\mathrm{ia}}-\mathrm{M}_{\mathrm{ia}}\right)}{-----}
$$

dengan:

$\mathrm{X}=$ ekspor

$\mathrm{M}=$ imppor

i dan a = barang jenis 'i' dan negara 'a'

Secara implisit, indeks ini mempertimbangkan sisi permintaan dan sisi penawaran. Ekspor identik dengan suplai domestik dan impor adalah permintaan domestik, atau sesuai dengan teori perdagangan internasional, yaitu teori net of surplus. Ekspor dari suatu barang terjadi jika ada kelebihan atas barang tersebut di pasar domestik. Nilai indeks ini mempunyai kisaran antara -1 sampai dengan +1 . Jika nilanya positif di atas 0 sampai 1 , komoditi bersangkutan dikatakan mempunyai daya saing yang kuat atau negara yang bersangkutan cenderung sebagai pengekspor dari komoditi tersebut (suplai domestik lebih besar daripada permintaan domestik). Sebaliknya, daya saing rendah atau cenderung sebagai pengimpor (suplai domestik lebih kecil dari permintaan domestik) jika nilainya negatif di bawah 0 hingga -1 . Jika indeks naik berati daya saingnya meningkat; begitu juga sebaliknya (Kementrian Perdagangan Republik Indonesia)

\section{HASIL DAN PEMBAHASAN}

\section{Neraca Perdagangan Internasional Indonesia-Amerika Serikat}

Hubungan Perdagangan Indonesia dan Amerika Serikat sampai saat ini masih merupakan kekuatan utama di dunia, baik dari sisi politik, militer, maupun ekonomi. Bagi Indonesia, AS merupakan salah satu mitra dagang utama, yakni setelah Republik Rakyat Cina dan Jepang. Total nilai 
ekspor Indonesia ke Amerika Serikat mencapai \$1.56 miliar, yang terdiri dari \$56 juta ekspor migas dan $\$ 1.5$ juta ekspor nonmigas. Sebaliknya, total ekspor AS ke Indonesia mengalami penurunan sebesar 7.84\%, dengan penurunan terbesar terjadi ekspor migas (mengalami penurunan lebih dari 50\%). Ekspor Indonesia ke AS terdiri dari karet, tekstil dan pakaian jadi, alas kaki dan mesin listrik. Sedangkan ekspor AS ke Indonesia terdiri dari produk pertanian, pesawat, mesin, dan kapas benang serta kain (dapat dilihat pada tabel 1). Nilai ekspor nonmigas Indonesia secara keseluruhan mengalami tren yang meningkat, kecuali tahun 2009 sebagai dampak dari krisis global. Angka ekspor Indonesia terhadap Amerika Serikat juga memiliki pola serupa, yakni meningkat sebesar 12,25\% pada 2008, lalu turun sebesar 16,77\% pada 2009; namun disusul kemudian dengan kenaikan pada 2010 dan 2011, masing-masing sebesar 31,49\% dan 15,37\% (Kementerian Perdagangan, 2012).

Neraca Perdagangan (Balance of Trade) merupakan bagian panting dari Neraca Pembayaran (Balance of Payment) yang merupakan ringkasan laporan rugi laba dari arus keluarmasuk barang, jasa dan aset dalam suatu perekonomian selama kurun waktu tertentu. Maka untuk dapat mengetahui hubungan perdagangan luar negeri Indonesia-Amerika, hubungan ekonomi kedua negara tersebut dianalisis dengan menggunakan data neraca perdagangan.

Tabel 1 Neraca Perdagangan Indonesia-Amerika Serikat Periode 2008 - 2012 (dalam ribu US\$)

\begin{tabular}{lrrrrrr}
\multicolumn{1}{c}{ URAIAN } & \multicolumn{1}{c}{$\mathbf{2 0 0 8}$} & \multicolumn{1}{c}{$\mathbf{2 0 0 9}$} & \multicolumn{1}{c}{$\mathbf{2 0 1 0}$} & \multicolumn{1}{c}{$\mathbf{2 0 1 1}$} & $\mathbf{2 0 1 2}$ & TREND \\
\hline T. PERDAGANGAN & $20.916 .939,2$ & $17.933 .955,6$ & $23.665 .785,2$ & $27.272 .345,3$ & $26.476 .998,5$ & 9,31 \\
MIGAS & $654.299,4$ & $426.290,7$ & $1.039 .952,2$ & $891.137,0$ & $417.198,9$ & $-1,61$ \\
NON MIGAS & $20.262 .639,8$ & $17.507 .664,9$ & $22.625 .833,1$ & $26.381 .208,2$ & $26.059 .799,5$ & 9,56 \\
EKSPOR & $13.036 .866,9$ & $10.850 .023,1$ & $14.266 .634,8$ & $16.459 .139,0$ & $14.874 .386,4$ & 7,04 \\
MIGAS & $505.756,4$ & $379.960,6$ & $940.172,0$ & $774.894,3$ & $283.445,4$ & $-4,36$ \\
NON MIGAS & $12.531 .110,5$ & $10.470 .062,5$ & $13.326 .462,8$ & $15.684 .244,7$ & $14.590 .941,0$ & 7,34 \\
IMPOR & $7.880 .072,3$ & $7.083 .932,6$ & $9.399 .150,4$ & $10.813 .206,3$ & $11.602 .612,1$ & 12,71 \\
MIGAS & $148.543,0$ & $46.330,1$ & $99.780,2$ & $116.242,8$ & $133.753,5$ & 7,36 \\
NON MIGAS & $7.731 .529,2$ & $7.037 .602,4$ & $9.299 .370,3$ & $10.696 .963,5$ & $11.468 .858,6$ & 12,83 \\
NERACA & $5.156 .794,7$ & $3.766 .090,5$ & $4.867 .484,3$ & $5.645 .932,7$ & $3.271 .774,4$ & $-4,93$ \\
PERDAGANGAN & $357.213,4$ & $333.630,4$ & $840.391,8$ & $658.651,5$ & $149.692,0$ & $-10,05$ \\
MIGAS & $4.799 .581,3$ & $3.432 .460,1$ & $4.027 .092,5$ & $4.987 .281,2$ & $3.122 .082,4$ & $-4,75$ \\
NON MIGAS & & & & & & \\
\hline
\end{tabular}

(Sumber: BPS, diproses oleh Pusat Data dan Informasi, Kementerian Perdagangan)

Neraca perdagangan Indonesia terhadap Amerika Serikat menunjukkan nilai yang positif, atau dengan kata lain nilai ekspor Indonesia ke Amerika Serikat lebih besar dibandingkan dengan nilai impor Amerika Serikat sendiri merupakan salah satu negara asal impor terbesar, bersama dengan negara-negara ASEAN, Jepang, dan Republik Rakyat Cina, serta negara-negara Uni Eropa (Tabel 1). Walaupun sempat mengalami penurunan pada tahun 2009, nilai impor Indonesia dari Amerika Serikat mengalami kenaikan tahun-tahun berikutnya. Sama seperti nilai ekspor Indonesia terhadap Amerika Serikat, nilai impor mengalami penurunan sebagai akibat dari krisis finansial yang melanda dunia, lalu diikuti oleh peningkatan pada 2010. Nilai impor Indonesia dari Amerika Serikat pada 2011 mencakup 6,09\% dari total impor Indonesia. Dibandingkan dengan proporsi dua tahun sebelumnya, yakni sebesar 7,32\% tahun 2009 dan 6,93\% pada 2010, angka ini menunjukkan penurunan (Kementerian Perdagangan, 2012). Walaupun tren keseluruhan sejak 2008 menunjukkan bahwa Indonesia memiliki nilai transaksi berjalan yang positif, awal tahun 2012 ditandai dengan defisit transaksi berjalan yang mencapai 3,1\% dari PDB. Nilai defisit transaksi berjalan ini sendiri sudah berangsur menurun, hingga mencapai 2,6\% dari PDB pada kuartal ketiga 2012. Walaupun nilai defisit tersebut masih bisa dikatakan relatif kecil, pemerintah Indonesia akan berupaya untuk mencegah agar nilai defisit tersebut tidak membesar dan tetap di angka 2,2\% - 2,5\%2. Selain itu, nilai defisit transaksi berjalan sebesar 
USD 561,1 juta pada periode Januari - Oktober 2012, salah satunya disebabkan oleh impor pesawat yang dilakukan Indonesia.

Defisit transaksi berjalan sendiri memang sering kali dianggap sebagai salah satu ukuran posisi sebuah negara dalam perdagangan internasional; bisa disebabkan oleh hal-hal positif dan juga negatif, sebagaimana yang diutarakan oleh Blanchard dan Milletti-Feresi (2010). Salah satu contoh alasan "buruk" timbulnya defisit transaksi berjalan dapat berupa kegagalan regulasi keuangan untuk mendukung pertumbuhan kredit, sedangkan alasan "baik" defisit transaksi berjalan termasuk harga barang ekspor yang rendah secara sementara. Defisit transaksi berjalan suatu negara secara signifikan dalam jangka waktu yang relatif panjang merupakan salah satu sinyal bahwa negara tersebut bukanlah tujuan eksporyang potensial, karena pemerintah negara tersebut kemungkinan akan menekan angka defisit transaksi berjalan. Defisit transaksi berjalan juga menunjukkan potensi pergerakan nilai mata uang suatu negara yang kemungkinan akan mengalami pelemahan (Eun dan Resnick, 2009). Defisit transaksi berjalan yang tinggi juga berisiko terhadap sudden stop dan berujung pada ketidakstabilan sektor keuangan. Oleh karena itulah, pemerintah berupaya untuk menjaga agar defisit transaksi berjalan tidak meningkat dan berlangsung permanen.

Tabel 2 Neraca Perdagangan Indonesia Total Periode 2008-2013 (dalam juta US\$)

\begin{tabular}{|c|c|c|c|c|c|c|c|}
\hline NO & URAIAN & 2008 & 2009 & 2010 & 2011 & 2012 & TREND \\
\hline \multirow[t]{3}{*}{ I } & E X P O R T & $137.020,4$ & $116.510,0$ & $157.779,1$ & 203.496,6 & $190.031,8$ & 12,88 \\
\hline & - OIL \& GAS & 29.126,3 & $19.018,3$ & $28.039,6$ & $41.477,0$ & $36.977,2$ & 13,39 \\
\hline & - NON OIL \& GAS & $107.894,2$ & $97.491,7$ & $129.739,5$ & $162.019,6$ & $153.054,6$ & 12,83 \\
\hline \multirow[t]{3}{*}{ II } & I M P O R T & $129.197,3$ & $96.829,2$ & $135.663,3$ & $177.435,6$ & 191.691,0 & 14,97 \\
\hline & - OIL \& GAS & $30.552,9$ & $18.980,7$ & $27.412,7$ & $40.701,5$ & $42.564,3$ & 15,33 \\
\hline & - NON OIL \& GAS & $98.644,4$ & $77.848,5$ & $108.250,6$ & $136.734,0$ & $149.126,7$ & 14,91 \\
\hline \multirow[t]{3}{*}{ III } & TOTAL & $266.217,7$ & 213.339,3 & $293.442,4$ & $380.932,2$ & $381.722,8$ & 13,89 \\
\hline & - OIL \& GAS & $59.679,2$ & $37.999,0$ & $55.452,3$ & $82.178,6$ & $79.541,5$ & 14,41 \\
\hline & - NON OIL \& GAS & $206.538,6$ & $175.340,2$ & 237.990,1 & $298.753,6$ & $302.181,3$ & 13,81 \\
\hline \multirow[t]{3}{*}{ IV } & BALANCE & $7.823,1$ & $19.680,8$ & $22.115,8$ & $26.061,1$ & $-1.659,2$ & 0,00 \\
\hline & - OIL \& GAS & $-1.426,6$ & 37,5 & 626,9 & 775,5 & $-5.587,0$ & 0,00 \\
\hline & - NON OIL \& GAS & $9.249,7$ & $19.643,2$ & $21.488,9$ & $25.285,5$ & $3.927,8$ & $-13,59$ \\
\hline
\end{tabular}

(Sumber: BPS, diproses oleh Pusat Data dan Informasi, Kementerian Perdagangan)

Tabel 3 Perkembangan Ekspor Nonmigas (Negara Tujuan Utama)

Periode 2008-2012 (dalam juta US\$)

\begin{tabular}{clrrrrrr}
\hline NO & URAIAN & $\mathbf{2 0 0 8}$ & \multicolumn{1}{c}{$\mathbf{2 0 0 9}$} & \multicolumn{1}{c}{$\mathbf{2 0 1 0}$} & $\mathbf{2 0 1 1}$ & \multicolumn{1}{c}{$\mathbf{2 0 1 2}$} & TREND \\
\hline 1. & RRC & $7.787,2$ & $8.920,1$ & $14.080,9$ & $21.595,6$ & $20.864,1$ & 33,05 \\
2. & JEPANG & $13.795,3$ & $11.979,0$ & $16.496,5$ & $18.330,1$ & $17.231,2$ & 9,09 \\
3. & AS & $12.531,1$ & $10.470,1$ & $13.326,5$ & $15.684,2$ & $14.590,9$ & 7,34 \\
4. & INDIA & $7.060,9$ & $7.351,4$ & $9.851,2$ & $13.279,0$ & $12.446,7$ & 18,83 \\
5. & SINGAPURA & $10.104,6$ & $7.947,6$ & $9.553,6$ & $11.113,4$ & $10.550,9$ & 4,31 \\
6. & MALAYSIA & $5.984,5$ & $5.636,4$ & $7.753,6$ & $9.200,1$ & $8.471,1$ & 12,58 \\
7. & KORSEL & $4.660,3$ & $5.174,3$ & $6.869,7$ & $7.565,8$ & $6.684,6$ & 11,64 \\
8. & THAILAND & $3.214,5$ & $2.598,4$ & $4.054,4$ & $5.242,5$ & $5.490,2$ & 19,39 \\
9. & BELANDA & $3.881,2$ & $2.902,9$ & $3.682,1$ & $5.076,3$ & $4.586,0$ & 9,34 \\
10. & TAIWAN & $2.901,2$ & $2.875,5$ & $3.252,3$ & $4.205,1$ & $4.094,1$ & 11,28 \\
& NON MIGAS & $107.894,2$ & $97.491,7$ & $129.739,5$ & $162.019,6$ & $153.054,6$ & 12,83 \\
\hline
\end{tabular}

(Sumber: Badan Pusat Statistik, diolah Kementerian Perdagangan) 
Indeks Spesialisasi Perdagangan (ISP) digunakan untuk menganalisis posisi atau tahapan perkembangan suatu produk. ISP dapat menggambarkan apakah suatu jenis produk Indonesia cenderung menjadi negara eksportir atau importir.

ISP Migas

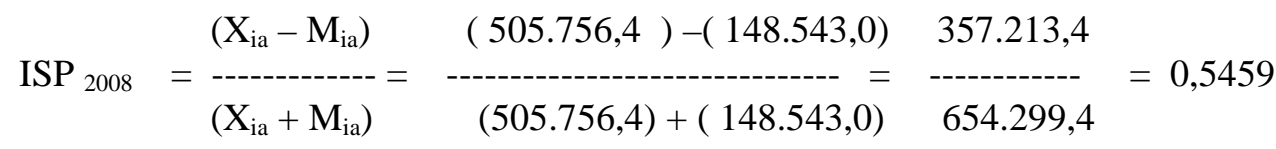

$$
\begin{aligned}
& \text { ISP }_{2009}=\frac{\left(\mathrm{X}_{\mathrm{ia}}-\mathrm{M}_{\mathrm{ia}}\right.}{-\left(\mathrm{X}_{\mathrm{ia}}+\mathrm{M}_{\mathrm{ia}}\right)}=\frac{(379.960,6)-(46.330,1)}{-(379.960,6)+(46.330,1)}=\frac{333.630,5}{-{ }^{2}}=0,7826
\end{aligned}
$$

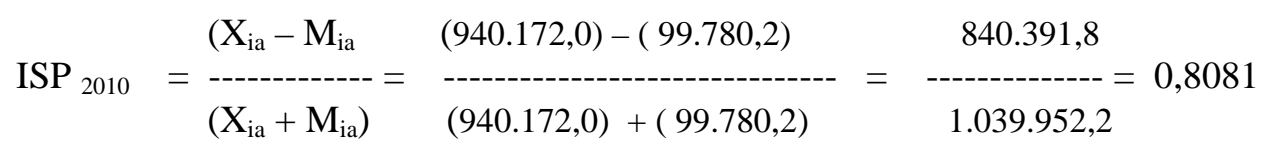

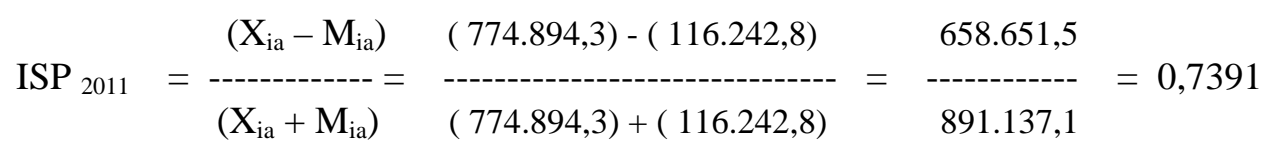

$$
\begin{aligned}
& \operatorname{ISP}_{2012}=\frac{149,6919}{--------}=0,35
\end{aligned}
$$

ISP Nonmigas

$$
\begin{aligned}
& \text { ISP }_{2008}=\frac{\left(\mathrm{X}_{\mathrm{ia}}-\mathrm{M}_{\mathrm{ia}}\right)}{\left.-\mathrm{X}_{\mathrm{ia}}+\mathrm{M}_{\mathrm{ia}}\right)}=\frac{12.531 .110,5-7.731 .529,2}{12.531 .110,5+7.731 .529,2}=\frac{4.799 .581,3}{2.026 .2639,7}=0,2369 \\
& \text { 3.432.460,1 } \\
& \mathrm{ISP}_{2009}=\frac{-----{ }^{-------}}{26 \cdot 381 \cdot 208,2}=0,1961
\end{aligned}
$$

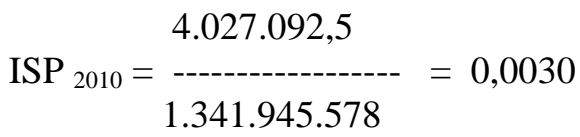

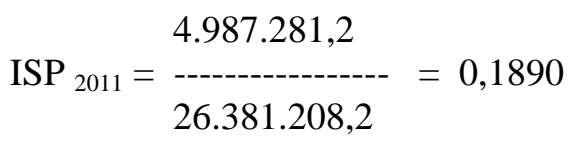

$$
\begin{aligned}
& \text { 3.122.082,4 } \\
& \text { ISP }_{2012}=\frac{-122.082,4}{26 \cdot 059 \cdot 799,6}=0,1198
\end{aligned}
$$

Nilai indeks spesialisasi perdagangan (ISP) baik untuk ekspor migas maupun nonmigas nilainya positif di atas 0 sampai 1 , maka komoditi migas maupun non migas mempunyai daya saing kuat. Artinya Indonesia cenderung sebagai pengekspor dari komoditi tersebut . Sebaliknya, Amerika Serikat daya saingnya rendah atau cenderung sebagai pengimpor. Akan tetapi, ISP untuk ekspor 
nonmigas sebagai produk unggulan Indonesia rasionya jauh lebih kecil dibandingkan dengan ISP migas.

Berdasarkan 10 jenis komoditas ekspor utama Indonesia ke Amerika, ekspor tekstil dan produk tekstil (TPT) merupakan penyumbang devisa terbesar di sektor industri karena memiliki daya saing relatif baik di pasar internasional sebesar 3.796,57 juta dolar Amerika pada 2008, 3.479,91 juta dolar Amerika pada 2009, 4.141,37 juta dolar Amerika pada 2010, 4.573,14 juta dolar Amerika pada 2011, dan 4.098,88 juta dolar Amerika pada 2012, atau rata-rata 4.017,97 juta dolar Amerika untuk 2008-2012. Komoditas karet dan produk karet tahun 2008-2012 sebesar 10.991,ii juta dolar Amerika atau rata-rata 2.198,22 juta dolar Amerika. Komoditas ini juga memiliki pangsa pasar yang cukup besar dari tahun ke tahun. Produk hasil hutan, otomotif, dan kakao juga punya prospek yang cukup besar. Berdasarkan komoditas ekspor nonmigas, 7 komoditas memiliki prospek ekspor tinggi pada 2011, antara lain tekstil dan produk tekstil (TPT), alas kaki, otomotif, kertas, kelapa sawit (CPO) dan produk turunannya, kakao olahan dan biji kakao, serta kopi.

\section{SIMPULAN}

Berdasarkan hasil analisis dan pembahasan, penelitian menyimpulkan sebagai berikut. Pertama, bagi Indonesia, AS merupakan salah satu mitra dagang utama, yakni setelah Republik Rakyat Cina dan Jepang. Kedua, neraca perdagangan Indonesia-Amerika membuktikan bahwa Indonesia memperoleh surplus perdagangan dengan Amerika sebesar 22.708,08 juta dolar Amerika selama kurun waktu 2008-2012. Ketiga, Amerika Serikat sendiri merupakan salah satu negara asal impor terbesar, bersama dengan negara-negara ASEAN, Jepang, dan Republik Rakyat Cina, serta negara-negara Uni Eropa (Tabel 1). Walaupun sempat mengalami penurunan pada 2009, nilai impor Indonesia dari Amerika Serikat mengalami kenaikan tahun-tahun berikutnya. Sama seperti nilai ekspor Indonesia terhadap Amerika Serikat, nilai impor mengalami penurunan sebagai akibat dari krisis finansial yang melanda dunia, lalu diikuti peningkatan tahun 2010. Keempat, rata-rata tingkat pertumbuhan ekspor barang Indonesia ke Amerika selama periode 2008-2012 sebesar 7,04\%. Rata-rata tingkat pertumbuhan impor barang Indonesia dari Amerika selama kurun waktu 5 tahun sebesar 12,71\%. Itu artinya rata-rata tingkat pertumbuhan ekspor barang Amerika ke Indonesia lebih besar 12,06 \% daripada rata-rata tingkat impor barang Indonesia dari Amerika. Kelima, nilai indeks spesialisasi perdagangan (ISP) baik untuk ekspor migas maupun nonmigas nilainya positif di atas 0 sampai 1 , maka komoditi migas maupun nonmigas mempunyai daya saing yang kuat. Artinya Indonesia cenderung sebagai pengekspor dari komoditi tersebut. Sebaliknya, Amerika Serikat daya saingnya rendah atau cenderung sebagai pengimpor. Namun ISP untuk ekspor non migas, sebagai produk unggulan Indonesia rasionya jauh lebih kecil dibandingkan dengan ISP migas. Keenam, berdasarkan 10 jenis komoditas ekspor utama Indonesia ke Amerika, ekspor tekstil \& produk tekstil (TPT) merupakan penyumbang devisa terbesar di sektor industri karena memiliki daya saing relatif baik di pasar internasional sebesar 3.796,57 juta dolar Amerika pada 2008, 3.479,91 juta dolar Amerika pada 2009, 4.141,37 juta dolar Amerika pada 2010, 4.573,14 juta US dolar pada 2011, dan 4.098,88 juta dolar Amerika pada 2012, atau rata-rata 4.017,97 juta dolar Amerika pada 2008-2012. Ketujuh, Negara tujuan ekspor 10 komoditi potensial adalah kulit dan produk kulit, peralatan medis, tanaman obat, makanan olahan, ikan dan produk perikanan, kerajinan, perhiasan rempah-rempah dan peralatan kantor.

\section{Rekomendasi}

Neraca perdagangan Indonesia-Amerika selalu menunjukkan bahwa Indonesia selalu mengalami surplus perdagangan dengan Amerika karena nilai ekspor barang Indonesia ke Amerika lebih besar daripada impor barang dari Amerika. Sebagai konsekuensi logisnya, Indonesia harus bersikap tetap menjaga hubungan internasional khususnya dengan Amerika Serikat dengan saling menghargai dan 
saling memberikan manfaat di dalam kebijakan luar negeri Indonesia. Sementara usaha-usaha meningkatkan cadangan devisa harus diupayakan secara maksimal dengan cara, di antaranya meningkatkan ekspor dan mengurangi impor balik secara volume maupun pangsa pasar serta menggalakkan diversifikasi ekspor. Kendati Amerika masih tetap menjadi pasar utama ekspor Indonesia, alternatif pasar baru harus menjadi target perdagangan Indonesia di kemudian hari. Pasar baru ini akan melahirkan keanekaragamkan komoditi ekspor baru.

\section{DAFTAR PUSTAKA}

Aimon, H. (2013). Prospek Perdagangan Luar negeri Indonesia-Amerika Serikat dan Kurs. Jurnal Kajian Ekonomi. Vol. 1, No. 02, Januari 2013, pp. 207-221.

Appleyard, D., Field, A., Cobb, S. (2006). International Economics. $5^{\text {th }}$ Edition. New York: McGraw Hill/Irwin.

Jukriadi. (2012). Makalah teori Perdagangan Internasional. Makassar: Universitas Muhammadyah Makasar.

Kementerian Keuangan Republik Indonesia. (2012). Kajian Kerja Sama Bilateral Indonesia -Amerika Serikat di Bidang Ekonomi dan Keuangan. Diakses 10 Desember 2013 dari http://www.kemenkeu.go.id/sites/default/files/Kajian_Kerja_Sama_Bilateral_RI-AS.pdf

Krugman, P. R. and Obstfeld, M. (2000). International Economics: Theory and Policy. University of California: Addison Wesley.

Mankiw, N. G. (2003). Teori Makro Ekonomi. Imam Nurmawan, Penerjemah. Jakarta: Indeks.

Siregar. (2009). Perdagangan Luar Negeri Indonesia-Amerika. Kajian. Vol. 14 No.3, September 2009, pp. 437-461. Diakses dari http://www.dpr.go.id/kajian/Perdagangan-Luar-Negeri-Indonesia Amerika-2009.pdf

Wikipedia. (2013). Perdagangan Internasional. Diakses 9 Desember 2013 dari http://id.wikipedia.org/wiki/Perdagangan_internasional. 


\section{LAMPIRAN}

Tabel 4 Negara Tujuan Ekspor 10 Komoditi Utama

\begin{tabular}{|c|c|c|}
\hline NO & KOMODITAS & NEGARA TUJUAN \\
\hline 1 & $\mathrm{TPT}$ & $\begin{array}{l}\text { AMERIKA SERIKAT, JEPANG, JERMAN, TURKI, KOREA SELATAN, } \\
\text { INGGRIS, UNI EMIRAT ARAB, REP.RAKYAT TIONGKOK, BRASILIA, } \\
\text { MALAYSIA, BELGIA, ITALIA, BELANDA, SPANYOL, KANADA, SAUDI } \\
\text { ARABIA, THAILAND, PERANCIS, VIETNAM, TAIWAN }\end{array}$ \\
\hline 2 & Elektronik & $\begin{array}{l}\text { SINGAPURA, AMERIKA SERIKAT, JEPANG, HONGKONG, REP.RAKYAT } \\
\text { TIONGKOK, JERMAN, MALAYSIA, BELANDA, KOREA SELATAN, } \\
\text { PILIPINA, PERANCIS, THAILAND, INDIA, AUSTRALIA, UNI EMIRAT } \\
\text { ARAB, INGGRIS, TAIWAN, VIETNAM, BELGIA, ITALIA }\end{array}$ \\
\hline 3 & $\begin{array}{l}\text { Karet dan } \\
\text { Produk Karet }\end{array}$ & $\begin{array}{l}\text { AMERIKA SERIKAT, JEPANG, REP.RAKYAT TIONGKOK, KOREA } \\
\text { SELATAN, SINGAPURA, BRASILIA, JERMAN, KANADA, BELANDA, } \\
\text { TURKI, PERANCIS, INDIA, SPANYOL, ITALIA, INGGRIS, BELGIA, } \\
\text { TAIWAN, REP.AFRIKA SELATAN, AUSTRALIA, ARGENTINA }\end{array}$ \\
\hline 4 & Sawit & $\begin{array}{l}\text { HONGKONG, INDIA, VIETNAM, REP.RAKYAT TIONGKOK, JERMAN, } \\
\text { SINGAPURA, KOREA UTARA, ITALIA, MALAYSIA, THAILAND, } \\
\text { SPANYOL, TAIWAN, JEPANG, KAMBOJA, SRI LANGKA, REP.AFRIKA } \\
\text { SELATAN, PERANCIS, PILIPINA, AMERIKA SERIKAT, MEKSIKO }\end{array}$ \\
\hline 5 & $\begin{array}{l}\text { Produk Hasil } \\
\text { Hutan }\end{array}$ & $\begin{array}{l}\text { INDIA, REP.RAKYAT TIONGKOK, MALAYSIA, BANGLA DESH, } \\
\text { BELANDA, MESIR, SINGAPURA, ITALIA, SPANYOL, UKRAINE, IRAN, } \\
\text { FEDERASI RUSIA, PAKISTAN, JERMAN, TANZANIA, BRASILIA, } \\
\text { REP.AFRIKA SELATAN, VIETNAM, MYANMAR, KENYA }\end{array}$ \\
\hline 6 & Alas Kaki & $\begin{array}{l}\text { JEPANG, REP.RAKYAT TIONGKOK, AMERIKA SERIKAT, KOREA } \\
\text { SELATAN, AUSTRALIA, MALAYSIA, TAIWAN, SAUDI ARABIA, UNI } \\
\text { EMIRAT ARAB, INDIA, JERMAN, BELANDA, INGGRIS, VIETNAM, } \\
\text { SINGAPURA, BELGIA, ITALIA, PERANCIS, BANGLA DESH, THAILAND }\end{array}$ \\
\hline 7 & Otomotif & $\begin{array}{l}\text { AMERIKA SERIKAT, BELGIA, JERMAN, INGGRIS, BELANDA, ITALIA, } \\
\text { JEPANG, MEKSIKO, PERANCIS, BRASILIA, REP.RAKYAT TIONGKOK, } \\
\text { DENMARK, PANAMA, KOREA SELATAN, SINGAPURA, SPANYOL, } \\
\text { AUSTRALIA, FEDERASI RUSIA, CHILI, REP.AFRIKA SELATAN }\end{array}$ \\
\hline 8 & Udang & $\begin{array}{l}\text { THAILAND, JEPANG, SAUDI ARABIA, PILIPINA, MALAYSIA, } \\
\text { SINGAPURA, UNI EMIRAT ARAB, REP.AFRIKA SELATAN, BRASILIA, } \\
\text { VIETNAM, REP.RAKYAT TIONGKOK, MEKSIKO, OMAN, KAMERUN, } \\
\text { TAIWAN, INGGRIS, MYANMAR, JERMAN, INDIA, KUWAIT }\end{array}$ \\
\hline 9 & Kakokao & $\begin{array}{l}\text { AMERIKA SERIKAT, JEPANG, REP.RAKYAT TIONGKOK, INGGRIS, } \\
\text { BELGIA, HONGKONG, VIETNAM, SINGAPURA, PERANCIS, KANADA, } \\
\text { AUSTRALIA, MALAYSIA, TAIWAN, FEDERASI RUSIA, BELANDA, } \\
\text { ITALIA, JERMAN, KOREA SELATAN, DENMARK }\end{array}$ \\
\hline 10 & Kopi & $\begin{array}{l}\text { MALAYSIA, AMERIKA SERIKAT, SINGAPURA, KOREA UTARA, } \\
\text { SPANYOL, JERMAN, PERANCIS, BELANDA, INGGRIS, AUSTRALIA, } \\
\text { PILIPINA, INDIA, KANADA, THAILAND, JEPANG, BRASILIA, UNI } \\
\text { EMIRAT ARAB, ESTONIA, FEDERASI RUSIA, SELANDIA BARU }\end{array}$ \\
\hline
\end{tabular}

Tabel 5 Negara Tujuan Ekspor 10 Komoditi Potensial

\begin{tabular}{lll}
\hline NO & KOMODITAS & \multicolumn{1}{c}{ NEGARA TUJUAN } \\
\hline 1 & Kulit dan & AMERIKA SERIKAT, JEPANG, JERMAN, ITALIA, MALAYSIA, BELGIA, \\
& Produk Kulit & INGGRIS, FEDERASI RUSIA, MESIR, MAROKO, INDIA, TAIWAN, \\
& & KANADA, AUSTRALIA, GEORGIA, SINGAPURA, ALJAZAIR, EKUADOR, \\
& & PERANCIS, REP.AFRIKA SELATAN \\
\hline 2 & Peralatan Medis & SINGAPURA, JERMAN, JEPANG, AMERIKA SERIKAT, INDIA, \\
& & REP.RAKYAT TIONGKOK, BELANDA, MALAYSIA, AFGANISTAN, \\
& & THAILAND, TAIWAN, KENYA, IRAN, KANADA, HONGKONG, \\
& & PERANCIS, AUSTRALIA, TIMOR TIMUR, SAUDI ARABIA, PILIPINA \\
\hline
\end{tabular}




\begin{tabular}{|c|c|c|}
\hline 3 & Tanaman Obat & $\begin{array}{l}\text { INDIA, MALAYSIA, AMERIKA SERIKAT, TAIWAN, JEPANG, } \\
\text { SINGAPURA, PERANCIS, BELANDA, JERMAN, SWISS, KOREA } \\
\text { SELATAN, VIETNAM, AUSTRALIA, HONGKONG, ARGENTINA, } \\
\text { THAILAND, INGGRIS, SAUDI ARABIA, UNI EMIRAT ARAB, YORDANIA }\end{array}$ \\
\hline 4 & Makanan Olahan & $\begin{array}{l}\text { AMERIKA SERIKAT, MALAYSIA, PILIPINA, SINGAPURA, JEPANG, } \\
\text { REP.RAKYAT TIONGKOK, KAMBOJA, THAILAND, VIETNAM, SAUDI } \\
\text { ARABIA, BELANDA, JERMAN, HONGKONG, AUSTRALIA, BELGIA, } \\
\text { INGGRIS, INDIA, SPANYOL, KOREA SELATAN, TAIWAN }\end{array}$ \\
\hline 5 & Ninyak Atsisi & $\begin{array}{l}\text { AMERIKA SERIKAT, SINGAPURA, PERANCIS, INDIA, SWISS, } \\
\text { SPANYOL, JERMAN, BELANDA, REP.RAKYAT TIONGKOK, INGGRIS, } \\
\text { MEKSIKO, UNI EMIRAT ARAB, TURKI, ITALIA, BRASILIA, JEPANG, } \\
\text { PAKISTAN, HONGKONG, TAIWAN, TIMOR TIMUR }\end{array}$ \\
\hline 6 & $\begin{array}{l}\text { Ikan dan Produk } \\
\text { Perikanan }\end{array}$ & $\begin{array}{l}\text { JEPANG, AMERIKA SERIKAT, THAILAND, VIETNAM, REP.RAKYAT } \\
\text { TIONGKOK, SINGAPURA, MALAYSIA, ITALIA, KOREA SELATAN, } \\
\text { HONGKONG, TAIWAN, SPANYOL, FEDERASI RUSIA, AUSTRALIA, } \\
\text { BELGIA, BELANDA, PERANCIS, JERMAN, INGGRIS, IRAN }\end{array}$ \\
\hline 7 & Kerajinan & $\begin{array}{l}\text { AMERIKA SERIKAT, JEPANG, INGGRIS, JERMAN, AUSTRALIA, } \\
\text { PERANCIS, BELANDA, KOREA SELATAN, SPANYOL, SINGAPURA, } \\
\text { ITALIA, KANADA, TAIWAN, BELGIA, REP.AFRIKA SELATAN, } \\
\text { MALAYSIA, SWEDIA, UNI EMIRAT ARAB, REP.RAKYAT TIONGKOK, } \\
\text { BRASILIA }\end{array}$ \\
\hline 8 & Perhiasan & $\begin{array}{l}\text { SINGAPURA, HONGKONG, REP.AFRIKA SELATAN, AUSTRALIA, } \\
\text { AMERIKA SERIKAT, UNI EMIRAT ARAB, JEPANG, ITALIA, BELANDA, } \\
\text { THAILAND, MALAYSIA, JERMAN, KOREA SELATAN, INGGRIS, } \\
\text { DENMARK, TURKI, SPANYOL, PERANCIS, SWISS, KANADA }\end{array}$ \\
\hline 9 & Rempah-rempah & $\begin{array}{l}\text { AMERIKA SERIKAT, VIETNAM, INDIA, BELANDA, SINGAPURA, } \\
\text { JERMAN, JEPANG, ITALIA, MALAYSIA, PERANCIS, REP.RAKYAT } \\
\text { TIONGKOK, AUSTRALIA, THAILAND, BELGIA, KOREA SELATAN, } \\
\text { BRASILIA, INGGRIS, FEDERASI RUSIA, KANADA, PAKISTAN }\end{array}$ \\
\hline 10 & Peralatan Kantor & $\begin{array}{l}\text { JEPANG, REP.RAKYAT TIONGKOK, THAILAND, SINGAPURA, } \\
\text { PILIPINA, MALAYSIA, BANGLA DESH, IRAN, SAUDI ARABIA, TURKI, } \\
\text { UNI EMIRAT ARAB, MESIR, AUSTRALIA, AMERIKA SERIKAT, } \\
\text { KANADA, MEKSIKO, BRASILIA, KOLUMBIA, BELANDA, JERMAN }\end{array}$ \\
\hline
\end{tabular}

